\title{
NOVA SLOVNICA: KJE SMO IN KAM GREMO
}

\section{Špela ARHAR HOLDT, Kozma AHAČIČ, Irena KRAPŠ VODOPIVEC, Simon KREK, Marko STABEJ, Rok ŽAUCER, Helena DOBROVOLJC, Vojko GORJANC, Polona GANTAR}

Arhar Holdt, Š., Ahačič, K., Krapš Vodopivec, I., Krek, S., Stabej, M., Žaucer, R., Dobrovoljc, H., Gorjanc, V. in Gantar, P. (2018): Nova slovnica: kje smo in kam gremo. Slovenščina 2.o, 6 (2): $1-32$.

DOI: http://dx.doi.org/10.4312/slo2.0.2018.2.1-32.

6. junija 2018 je na Inštitutu Jožef Stefan ${ }^{1}$ potekal dogodek, na katerem so bili javnosti predstavljeni cilji in prvi rezultati projekta Nova slovnica sodobne standardne slovenščine: viri in metode (ARRS J6-8256). Namen projekta, ki ga natančneje opredeljuje predstavitvena spletna stran, ${ }^{2}$ je razviti jezikoslovno metodologijo za računalniško podprto analizo sodobne slovenščine, kakršna je zajeta $\mathrm{v}$ referenčnih besedilnih korpusih slovenskega jezika. $\mathrm{Z}$ novo metodologijo bodo pripravljene baze jezikovnih podatkov, ki bodo po koncu projekta skupnosti odprto na voljo za raziskave, gradnjo jezikovnih priročnikov ter učnih gradiv, razvoj jezikovnotehnoloških orodij ipd.

Omenjeno projektno financiranje izdelave kakršnegakoli zaključnega izdelka sicer ne pokriva, vendar že priprava podatkovnih baz zahteva premisleke o trenutnih prioritetah slovenskega prostora. Med cilji za prihodnost je brez dvoma sodobni slovnični opis, ni pa še v konsenza, kako naj bo slednji oblikovan, da bo odgovoril na (različne) potrebe sodobne družbe. Da odpremo razpravo, smo na projektnem dogodku organizirali strokovni posvet, opredeljen z naslednjimi vprašanji: kdo so deležniki, ki bi lahko projektne rezultate uporabljali; na kaj moramo pri pripravi paziti, da bodo podatki optimalno uporabni; kakšno oz. katero slovnico potrebujemo najprej; katere so metodološke in logistične premise njene priprave; kje je trenutno slovensko

1 https://ijs.si/ijsw

2 http://slovnica.ijs.si/ 
slovničarstvo in kakšen razvoj si lahko obetamo; kakšne so potrebe po slovničnih podatkih pri različnih uporabniških skupinah ter kaj bi trenutne vrzeli najbolje naslovilo.

Na posvetu so sodelovali: dr. Kozma Ahačič (Inštitut za slovenski jezik Frana Ramovša, ZRC SAZU), dr. Irena Krapš Vodopivec (Škofijska gimnazija Vipava), dr. Simon Krek (Laboratorij za umetno inteligenco, Inštitut Jožef Stefan), dr. Marko Stabej (Oddelek za slovenistiko, Filozofska fakulteta Univerze v Ljubljani) in dr. Rok Žaucer (Center za kognitivne znanosti jezika, Univerza v Novi Gorici). Vsak izmed sodelujočih je dobil čas za predstavitev uvodnih tez oz. vprašanj, sledila je razprava, ki sem jo moderirala dr. Špela Arhar Holdt (Center za jezikovne vire in tehnologije, Univerza v Ljubljani).

Zapis je po posnetku dogodka3 ${ }^{3}$ pripravil Haris Agović. Pri zapisu so bile izjave za namene lažjega branja skladenjsko prilagojene značilnostim pisnega jezika, vendar po principu minimalne intervencije. Govorke in govorci so opis pregledali in predlagali (nevsebinske) popravke za boljše razumevanje besedila. Zapis začenjamo z nastopom prvega panelista.

Kozma Ahačič: Hvala za besedo. Najprej bi v svoji uvodni besedi opozoril na tri sestavne dele slovnic vseh vrst, ki se jih mora po mojem ločevati, ko se govori o preteklih, sodobnih in prihodnjih slovnicah. Prvi del je teoretično izhodišče slovnice. Manj ko je slovnica, ki izhaja iz korpusa in jezikovnotehnološke obdelave, teoretično obremenjena, bolj ko so kategorije preproste in jasno razmejene, lažja je njena izdelava, podatki pa bolj zanesljivi. To kažejo izkušnje, tudi iz tujine. Slabost teoretično manj obremenjene slovnice pa je, da ne rešuje mejnih primerov v jeziku in služi bolj za izhodišče kot za popoln opis jezika. Kljub temu se mi zdi primernejši prvi korak za korpusno slovnico.

Drugi del, ki bi ga izpostavil, je realno jezikovno gradivo. Realno jezikovno gradivo skoraj praviloma zastavljeni teoretični okvir postavlja pod vprašaj.

3 http://videolectures.net/novaslovnica2018_ljubljana/ 
Moja temeljna izkušnja4 (in to na precej bolj osnovni ravni, kot se je loteva pričujoči projekt) je, da pri pripravi slovnice niso problem posamezna poglavja in izolirana vprašanja, ampak je problem celota. Noben jezikovni pojav namreč ne more ostati izven slovnice, ker slovnica ne opisuje dela jezika, ampak jezik v celoti. Nek slovnični opis se mora torej znotraj sebe iziti za vse primere, ki živijo $\mathrm{v}$ določenem jeziku. Odločitev o tem, ali bomo v slovnici na primer na ravni besednih vrst operirali s pojmi kot so členek, povedkovnik in tako naprej, ali pa bomo vse to označevali kot prislove, je tako stvar teoretičnega izhodišča. $\mathrm{Na}$ ravni gradiva pa nas to ne reši zagate, kako opisati nenavadno vedênje posamičnih skupin besed ne glede na njihovo kategorialno uvrstitev. Prav tako nas večja ali manjša vključitev pojmovanja konverznosti v teoretični okvir ne odreši razreševanja tega problema na ravni gradiva, saj se bo v gradivu isti leksem v različnih pozicijah lahko vedel popolnoma različno. Manjša obremenjenost $\mathrm{s}$ teoretičnimi razmisleki na ravni teoretičnega izhodišča slovnice tako ne pomeni manj dela s slovničnim opisom, ampak zgolj preložitev oziroma odložitev problema z ene ravni na drugo. Če sem navedel samo nekaj preprostih oblikoslovnih problemov, se na ravni skladnje in besednega reda ti problemi prav neverjetno namnožijo.

Poleg tega ima vsak jezik vsaj nekaj oblikoslovnih in skladenjskih primerov, ki jih težko objektivno kategoriziramo. Značilen primer za slovenščino sta besedi lahko in rad ter njuna skladenjska raba. $\mathrm{Z}$ vidika leksikalnega opisa se nam takšne zagate hitro pokažejo, ko je treba celotno slovensko leksiko uvrstiti v posamezne besedne vrste, ji določiti konverznost, skladenjske vloge, stalnost besednih zvez, dvojničnost, potem pomen, ki je vezan na posamezne slovnične kategorije, pomen $\mathrm{v}$ predikativni rabi in seveda slovnični učinek, ki ga povzročajo tako imenovane slovnične vrste (kot so na primer vezniki). Realno jezikovno gradivo nas torej ne glede na teoretični okvir postavlja pred primere, ko se moramo odločiti. Uporabnik, ki bo slovnico uporabljal kot priročnik ali 
kot osnovo za nadaljnje raziskovanje, bo namreč osredotočen predvsem na mejne in nejasne primere, ne na primere, ki jih lahko razreši že na podlagi osnovnega jezikovnega znanja. Prav zato je golo oblikoslovje pregibnih besednih vrst del slovnice, ki ga je relativno najlažje dobro opisati, saj na tej ravni praviloma vemo, kaj iščemo.

Zadnji, tretji del, ki bi ga izpostavil, je vprašanje zvrstnosti. Če to vprašanje ni razrešeno na začetku (in tu je za operativno delo povsem vseeno, ali operiramo s pojmom standardnega ali s pojmom knjižnega jezika), nas bo v vprašanje zvrstnosti prisililo gradivo samo. Že samo na ravni standardnega ali knjižnega jezika bomo namreč lahko opazovali zelo različne glasoslovne, oblikoslovne, besedotvorne in skladenjske uresničitve, ki jih bomo lahko pojasnjevali samo ob ustrezni vezanosti na tip besedil, v katerih jih najdemo. Če gremo proti prihodnji slovnici, bi sklenil samo še s tem, da moramo paziti, da ne bi bila takšna slovnica zgolj stranski produkt jezikovnotehnoloških potreb in možnosti - da bi se slovnico dejansko delalo kot osnovni cilj že od začetka. Hvala.

Špela Arhar Holdt: Najlepša hvala, lahko kar Irena.

Irena Krapš Vodopivec: Hvala, lepo pozdravljeni, hvala za besedo. Jaz se bom zadeve lotila veliko manj znanstveno oziroma čisto iz prakse. Sedemnajst let že učim slovenščino na gimnaziji in zato bom $\mathrm{v}$ zvezi $\mathrm{z}$ današnjo temo izhajala s tega področja. Začela bi s tem: če govorimo o gimnazijah, še vedno velja predpostavka, da na gimnazije prihajajo najboljši učenci. Ob sicer množičnejšem vpisu je odličnosti nekoliko manj, pa vendar je podatek pomemben, ker gimnazijci na koncu opravljajo maturo iz slovenščine. Čeprav gimnazija seveda predstavlja le segment v izobraževalni vertikali, so rezultati na maturi tako ali drugače pokazatelj razvoja jezikovne zmožnosti skozi celotno vertikalo. Rezultati na maturi iz materinščine pa niso spodbudni. Če pogledamo lanske rezultate (po RIC-ovih podatkih), so bili gimnazijci pri slovenščini le malo nad povprečno oceno. To se pravi približno dobro, nekaj čez. Ampak govorimo o vseh treh ravneh ocenjevanja. Če izpustimo ustno ocenjevanje, če 
gremo samo k eksternemu, pisnemu ocenjevanju, so rezultati še nižji.

Kako je to povezano z današnjo temo? Od začetkov svojega dela do danes sem pri jezikovnem pouku zamenjala že nekaj gradiv, prenovljen je bil učni načrt, zares spremenilo pa se po moji presoji ni prav veliko. Slovnične in pravopisne vsebine se še vedno podajajo v obliki tradicionalnega opisa, in sicer je glavni razlog pomanjkanje časa ob pripravi na maturo; o tem bom nekoliko več povedala kasneje. Vedno pogosteje se mi ob pregledovanju, popravljanju besedil, ki jih tvorijo dijaki, potrjuje opažanje, da pišejo v knjižnem jeziku najpogosteje tako, kot so navajeni govoriti v svojem narečju oziroma neknjižnih sporazumevalnih okoliščinah - v smislu pretvarjanja tega v knjižni jezik. Tisti z nekoliko več jezikovnega čuta so pri pretvarjanju uspešnejši. Pravopisnoslovnični opis (tak, kot je zdaj v šoli) pa k temu po mojih izkušnjah ne prispeva dovolj.

Pri pouku sama poskušam upoštevati dejstvo, da so dijaki rojeni govorci slovenščine, da v sporazumevalni resničnosti živijo, jo sooblikujejo, pa čeprav v neknjižnih zvrsteh. Zato mislim, da bi morali pri poučevanju maternega jezika, predvsem pri slovnično-pravopisnem opisu, izhajati iz dejstva, da se mladi jezika ne učijo v celoti na novo in da opis jezika za izboljšanje njihove sporazumevalne zmožnosti ni tako bistven. Seveda ga je treba smiselno vključiti v proces učenja - po moji presoji s precej bolj individualiziranim pristopom. Torej z veliko tvorjenja besedil v obeh prenosnikih in z ozaveščanjem napak ob svojih besedilih in pomnjenjem pravil ob tem. Zdi se mi, da gre pri pouku materinščine pravzaprav za korekcijo že naučenega. To je po moji presoji težji proces kot prvo pomnjenje, s čimer se srečujejo dijaki pri učenju tujega jezika. Nezanemarljivo je dejstvo, da je narečno obarvani sleng prvi jezik dijakov oziroma edini jezik, s katerim se mladi zares poistovetijo. $V$ knjižni slovenščini jim je komuniciranje tuje, v obeh prenosnikih. Mogoče malo bolj naravno v pisni slovenščini, absolutno pa ne v govorjeni. Avtentičnih priložnosti za to znotraj šolskega procesa ni veliko in seveda ne tako želene notranje motivacije. Pri pouku tujega jezika je notranje motivacije pri dijakih absolutno več. Poleg 
tega da se od začetka učijo knjižne zvrsti, imajo tudi veliko več avtentičnih možnosti za uporabo jezika.

Pred leti sem zato poskusila izvajati nekoliko prilagojeno izpolnjevanje učnega načrta: manj frontalnih slovničnih opisov in veliko več samostojnega dela, več tvorjenja različnih besedil in kvalitetno individualizirano povratno informacijo. Težava je seveda čas, ampak moji dijaki po tej spremembi na maturi dosegajo enake - tukaj pa operiram s številkami, ne govorim na pamet - enake ali boljše rezultate, kot so jih prej. To se pravi, sposobni so se sami opremiti z orodji, da poiščejo opise jezika, ko je potrebno; kot mi sami povedo (spet v anketah), to tudi hitro pozabijo. Po tem procesu pa, vsaj tako pravijo, odhajajo z gimnazije s precej večjo samozavestjo pri rabi knjižne slovenščine, kar je seveda cilj učnega načrta, $\mathrm{z}$ védenjem, da zmorejo komunicirati $\mathrm{v}$ knjižnem jeziku, in $\mathrm{z}$ zavedanjem, da je učenje maternega jezika vsaj toliko pomembno in smiselno kot učenje tujega jezika. Kar pa po mojem v današnji dobi, v 21. stoletju, pri razvijajočih se mladostnikih pomeni pravzaprav uspeh.

Kaj vidim kot osrednje težave $\mathrm{v}$ zvezi s slovničnim opisom $\mathrm{v}$ šoli, torej $\mathrm{v}$ gimnaziji? Če sem konkretna: po mojem je glavna težava izhajanje iz predpostavke, da dijaki nimajo jezikovnega predznanja. To še posebej velja pri gimnazijcih, ker celotni slovnični opis poslušajo že v osnovni šoli. Tu bi lahko čas pridobili. [Druga težava je] prepričanje, da bodo dijaki samozavestni govorci slovenščine, če bodo obvladali pravila. Korelacija med pravili in rabo je precej nerealna; tudi o tem bom, upam, kakšno besedo lahko rekla še kasneje. Tretja težava: prenatrpanost učnega načrta za slovenščino v gimnazijah, absolutno. In zato premalo časa za tisto, kar je bistveno, torej za samostojno tvorjenje, za rabo jezika in seveda ob tem tudi pomnjenje pravil. Sprašujem se, ali se v resnici z dijaki skozi štiri leta pripravljamo na maturo ali se pač učimo jezika oziroma poskušamo vzpostaviti možnost, da bo dijak postal samozavesten tvorec v knjižnem jeziku. To dvoje se namreč zelo pogosto žal izključuje, zato se vedno znova vračam $\mathrm{k}$ temu, da bi bilo treba premisliti o smiselnosti tovrstnega preverjanja znanja. Ker je jasno, kam se bo pouk 
usmeril, če bo treba izbirati. Usmerili se bomo v pripravo na maturo, ne pa v razvoj zmožnosti in rabe knjižnega jezika, zato ker je tak čas. Dijak, ki bo imel slabše rezultate na maturi, se ne bo mogel vpisati na želeno fakulteto in tako naprej.

Zaradi tega je v šoli še vedno veliko preveč teorije. Kljub temu da je po prenovi učnega načrta načeloma pristop izbesedilen, je še vedno veliko, veliko premalo prakse. Torej ni avtentičnih možnosti za to, da bi opis uporabili. Veliko več je tega pri tujem jeziku. Težavo vidim še $\mathrm{v}$ tem, da je podajanje snovi pri mnogih drugih predmetih $\mathrm{v}$ gimnazijah pogosto $\mathrm{v}$ nestandardnem jeziku. To spet pomeni eno avtentično možnost za srečevanje s knjižnim jezikom manj. Težava je, da je današnji pouk manj uniformiran, da se učitelji, profesorji borijo za dijake, zato se vzpostavlja precej manj formalne okoliščine in to pomeni tudi hiter zdrs v nestandardni jezik. In še zadnje: težava je ponovno in še enkrat čas. Ker imajo dijaki zelo različno razvito sporazumevalno zmožnost, bi bilo treba vsakemu posebej podati kvalitetno povratno informacijo o njegovem tvorjenju. Na ta način bi se seveda učil tudi pravil. Hvala lepa.

Špela Arhar Holdt: Hvala, super. Izvoli.

Simon Krek: Vseeno moram poudariti par stvari z izhodišča projekta, ki danes organizira ta dogodek. In sicer, da ne bo kakšne dileme - to ni projekt, ki bi proizvedel novo slovnico slovenščine. To je projekt, katerega cilj je proizvesti podatke, na katerih je mogoče narediti slovnico v kateremkoli teoretskem okviru želimo. Na nek način tukaj lahko izpostavim projekt, kot je Survey of English Usage 5 iz petdesetih let, ki je imel empirično izhodišče: »Ne bomo delali angleške slovnice, če ne vemo, kakšni so v resnici empirični podatki«. To so naredili s takratnimi možnostmi in iz tega je nastala Quirkova slovnica. ${ }^{6} \mathrm{~V}$ zdajšnjem času, se pravi leta 2018, imamo neskončno več možnosti za empirično preverjanje vseh jezikovnih pojavov in to je $\mathrm{v}$ resnici tudi namen - 
da jih organiziramo na način, ki je potem dostopen vsem.

Drugi del, ki ga je pomembno poudariti, je ta: ne glede na to, kar si kdorkoli misli o čemerkoli, je treba omogočiti računalniško analizo vseh jezikovnih pojavov, ki jih kdorkoli producira v slovenščini z intenco, da ga nekdo razume. To je drugačno izhodišče od tega, če rečemo, da bomo na nek način preverili sistemsko pravilnost tvorjenih stavkov. Znati moramo interpretirati čisto vsak stavek, ki ga nekdo skomunicira komurkoli, tudi računalniku. Ta del bo v resnici tudi pokrit, tukaj ni težave, čeprav je seveda veliko dela. Ta del je pomemben za slovenščino tukaj in zdaj. Če samo nakažem, za kaj gre. Imeti moramo formalizirano slovnico, ki je računalniško berljiva. Kar se tiče skladnje, imamo ta hip denimo model odvisnostne drevesnice. Prihaja iz praške šole, prihaja iz češčine, to je okej, ker je vseeno tudi slovansko. To je del, ki ga je treba pokriti ne glede na to, kaj bomo potem naredili s slovnico za človeške konzumente.

Zadnja stvar, ki jo želim poudariti, je to, kar sem že omenil v prejšnjem delu diskusije, ko smo predstavljali,7 in sicer, da imamo na nek način dva loka, ki ju nočemo ločevati med sabo. En je leksikogramatični. Če vzamemo in analiziramo neke pojave, v resnici ni dobro, da [jih] ločujemo na nekaj, kar naj bi bila strogo skladnja ali strogo morfologija, s semantiko se pa pač ne bomo ukvarjali, ker so drugi ljudje, ki se ukvarjajo s tem, recimo leksikografi. V tem smislu je treba reči, da v bistvu ni slovarja brez slovnice. Kdorkoli se bo lotil jezikovnega opisa slovenščine za 21. stoletje, bo moral imeti tudi slovnične kategorije, ki po možnosti temeljijo na empiričnih podatkih tega, kar proizvajajo ljudje, da bi komunicirali z drugimi. To je izhodišče: da imamo en lok. Recimo, da si jezikoslovci želijo imeti ločene vrtičke in se ukvarjati s frazeologijo, ki je čisto nekaj drugega od kolokacij, ki je čisto nekaj drugega od vezljivosti in tako naprej. To je en in isti lok, ki ga je Sinclair opisal z 'idiom principle' - v smislu organizacije jezika zato, da bi lahko komunicirali pomen. Ene stvari, ki nosijo pomen, so večje, druge so manjše. Mogoče gre do morfema 
ali do frazeologije na drugi strani, ampak tega ni mogoče ločevati na neke trde dele, s katerimi se radi ukvarjamo. Toliko o tem.

Marko Stabej: Hvala lepa. Hvala za povabilo. Kot se mi vidi, nisem slovničar, sem samo simpatizer. Vidi se pa tudi, da rad zajemam z veliko žlico, prebava pa malo slabše deluje. To je prispodoba za to, kar čutim o sodobnem slovničarstvu. Zdi se mi, da podatkov ne more biti nikoli premalo, ker je bila to največja pomanjkljivost preteklih obdobij, deloma objektivna, deloma ideološka. Odsev te ideologije se kaže v tem, da je še vedno v obtoku termin gradivo. 'Gradivo' ni isto kot 'podatki'. Gradivo je nekaj, kar v jeziku najdeš, s čimer in na čemer lahko gradiš svoje teoretske predpostavke. Zdi se nam, da je normalna povratna zanka, da s tem potem realnost pojasnjuješ. Ampak zgodovina slovenske slovnice je v tem, da se to ne zgodi. $V$ tem smislu se mi zdi, da moramo imeti pri slovnici ... Bi bilo fajn, no, če bi imela naša interdisciplinarno zasnovana znanstvena skupnost maksimalni program, ki ga je postavil že Bezlaj. Jaz sem bral Bezlaja leta '64 v eseju Blišč in beda slovenskega jezika, kjer pravi, da bolj kot česarkoli Slovenci potrebujemo slovnice. Ne slovnice standardnega jezika, ne slovnice posameznih narečij, ampak slovnice, ki bi teoretsko pojasnila sleherno izjavo v slovenskem jeziku. To je seveda maksimalni program, da te zaboli glava, če samo pomisliš, kako bi bilo to možno. Ampak brez maksimalnega programa ostajamo v nekem parcialnem opisu, kjer ne vemo, ali predpisujemo, opisujemo, kaj opisujemo, ali se s tem, da opisujemo, komu zdi že, da predpisujemo. Vse to, kar se danes pravzaprav dogaja.

Zanimivo, da je to pisal '64, ko se je Toporišičeva slovnica že pripravljala in je bila dolgo časa - mi smo bili navajeni nekako privzeti - odrešitev vsega, kar je bilo problematično. $\mathrm{Na}$ to ste nekateri iz publike že opozarjali: takega hibridnega jezikoslovnega dela, kot je Toporišičeva slovnica, zlepa ne najdeš, ker je normativno, deskriptivno, ne vem, kaj vse. Pravzaprav logičen nasledek je, da je bil slovnični opis izrazito parcializiran. Postavlja se mi naslednje vprašanje, analogno z recimo zgodovinopisjem, ki ugotavlja, da velike zgodbe, (velike zgodovine, dvanajst tomov, zgodovina francoske države) pravzaprav 
niso možne, ne da bi temeljito lagal. Ker veš toliko podatkov, toliko nasprotujočih si silnic, da če govoriš samo zgodovino zmagovalca, pač ne govoriš resnice. Ne rekonstruiraš resnice, ampak rekonstruiraš zgodbo, ki ti paše kot zmagovalcu. Tudi zgodba slovničarja kot neke vrste avtoritarnega obvladovalca te zgodbe - to si je Toporišič vzel, vsi vemo. Ampak zgleda, da mu je tako uspelo (ali pa tako neuspelo), da si tega vsaj do zadnjega časa ni nihče niti v sanjah upal prevzeti.

Če lahko povem malo notranje informacije: tudi na Katedri za slovenski knjižni jezik na Filozofski fakulteti Univerze v Ljubljani ${ }^{8}$ smo v preteklih dvajsetih, petindvajsetih letih na več raznih sejah oziroma sestankih (zdaj že nekaj časa ne) imeli na sporedu, kaj če bi se lotili pisanja slovnice. Ampak ker smo se seveda zavedali metodološke, teoretske različnosti, dlje kot do tega vprašanja pravzaprav ni nikoli prišlo. Ker je bilo vprašanje: na podlagi česa, komu in zakaj pišeš to veliko zgodbo.

Zdi se mi, da se je tega dobro zavedati in s tega stališča se mi zdi projekt [Nova slovnica sodobne standardne slovenščine] res odličen začetek. Podatkovje mora biti tukaj, potem pa se izluščijo take ali drugačne zgodbe. Samo ena velika zgodba po mojem ni možna. To se vidi v šolski slovnici (imam srečo, da prakse ne poznam več kot toliko). Tudi za šolsko slovnico rečemo: »Aha, to pa je žanr«. Ampak ali je to žanr nečesa, kar naj bi pomagalo pri mejnih primerih, kot je rekel kolega Ahačič? Da ne veš, kaj, pa pogledaš v slovnico in rečeš: »Aha, zdaj pa vem«. Zakaj bi to pravzaprav počel? Marsikdaj se lahko zgodi, da obstaja v realnosti A in B. In pogledaš v slovnico, ki pravi: »Raje B «. Pa ne veš, zakaj »raje $\mathrm{B}$ «. Ker se slovničarju kot pripovedovalcu tako zdi bolje ali ker je bolj utemeljeno v skladu s tradicijo? To je ena stvar. Po drugi strani pa je moj občutek in moja starševska izkušnja, da otrok najprej rabi metajezikovni nabor oznak, s katerimi jezik sploh lahko napade. Ne da bi hotel imeti ta jezik opisan, ampak hoče nečemu, za kar mi vemo, da je pridevnik, reči pridevnik. In to sploh

8 https://www.slov.si/ 
ni slovnica, ampak nabor metajezikovnih oznak. Ki se jih je zdaj, kot vemo, treba izogibati, da ne bi prekmalu rekli česa premalo dokončnega o katerikoli stvari. Pri čemer dokončne resnice - to pa je, hvala bogu, zadnjih deset let prineslo - ni. To bi jaz rekel. Hvala lepa.

Rok Žaucer: Hvala. Jaz si bom pomagal, nisem tak govorec, da bi znal govoriti na pamet. Dobili smo dva sklopa stvari, o katerih naj razmislimo, in jaz sem splošnejši sklop vzel za podlago za kratko [predstavitev], drugo pa sem si napisal na plonk ceglc. Eno od splošnih vprašanj, na katero naj bi odgovarjali na posvetu, je: Kakšno oziroma katero slovnico potrebujemo najprej? Ideja je, če obstajajo, če se da določiti nacionalne prioritete in potrebe. Kar se tega tiče, mi je s stališča generativnega jezikoslovca jasno, da ne glede na moje potrebe rabi slovenščina orodja, s katerimi se jo da omogočiti za boljšo uporabo $\mathrm{v}$ digitalnem okolju. Je za to potrebna slovnica? Če je, rabimo tako slovnico najprej. Ne vem pa, da bi za take stvari slovnica bila potrebna - da bi Google, preden je naredil prevajalnik, naredil slovnico in tako naprej. Pri vsem ostalem se mi zdi, da je [odgovor], kaj se najbolj rabi, odvisen od tega, koga bomo vprašali. Kakorkoli bomo obračali, bomo prišli do tega, da bo zgodovinski jezikoslovec rekel: »Jaz rabim pač to«. Konec koncev lahko reče: »Splošno slovnico imamo, zgodovinske slovnice nimamo, dajmo narediti to najprej.« Teoretični jezikoslovec (kjer 'teoretični' pomeni samo cilj pristopa, ne da teoretični jezikoslovci niso empirični jezikoslovci) bo rekel, da rabimo razlagalno opisno slovnico. Učitelju slovenščine kot tujega jezika, recimo specifično za govorce kitajščine, bo prišlo prav nekaj drugega in tako naprej.

Širši konsenz bomo, po mojem mnenju, težko dobili in v nekem smislu nisem prepričan, da je blazno nujen. Seveda zmeraj pomaga, ampak nujen je, če bo eno ali drugo ali tretje ministrstvo reklo: »V naslednjih dvajsetih letih financiramo eno samo stvar.« Potem rabimo širši konsenz. Do neke mere nedavna zgodovina kaže, da se da dobiti tudi neodvisno financiranje, se pravi neodvisno od modela, kot sem ga zdaj omenil. Kozma ima šolsko slovnico, ki ni bila financirana na tak način. V tem smislu so učbeniki za slovenščino kot tuji 
jezik, kot jih dela Center za slovenščino kot drugi ali tuji jezik, 9 Rada Lečič, tudi na te stvari se da gledati kot na nek tip slovnice. Razmišljamo lahko tudi o odprtem wikiju, ki ga lahko dopolnjujemo vsi. Nekaj takega se je usedlo na UNG-jev ${ }^{10}$ strežnik. Izključno samo zametek in ne izgleda, da bo lahko hitro karkoli ratalo.

Če pogledamo tuje prakse, obstajajo tudi generativno zasnovane knjige, ki jim lahko rečemo slovnica, recimo Cambridge Syntax Guides ${ }^{11}$ obstajajo za velike in majhne jezike, za recimo valižanščino, za islandščino. To je financiral Oxford University Press, do neke mere, vsaj izdajo. Ostalo pa je v rednem financiranju, jezikoslovca univerza plačuje, da je jezikoslovec na tisti univerzi. Peter Jurgec ima narejen velik del za fonologijo slovenščine, ki mu jo je financirala Nizozemska znanstvena fundacija ${ }^{12}$ in tako naprej. Mislim, da ni nujno, neobhodno, da imamo nek širši konsenz.

Druga stvar je še: Kje je trenutno slovensko slovničarstvo in kakšen razvoj si lahko obetamo. Mi je malo težko odgovoriti. Lahko bi rekel, da mogoče niti ne vemo. Vemo, kako zgleda tradicionalna slovenska slovnica, ampak če bomo dobili še eno, pri tem ne bomo govorili o razvoju. Kako bo zgledala slovnica, ki bo res močno jezikovnotehnološko osnovana? Po mojem še ne vemo. Težko rečemo, kje smo, kar se tega tiče. Kako bi zgledala razlagalno-opisna generativno zasnovana slovnica, tudi ne vemo, ker tega nimamo. Lahko sklepamo po primerih tistih parcialnih The Syntax of Welsh ${ }^{13}$, pa od Petra Jurgca fonologija in podobno, ampak težko bi bilo oceniti. Izgleda, da bo sočasno nastajalo več slovnic, ki bodo odgovarjale na različne potrebe različnih uporabnikov. Konec koncev je Kozma to nekoč že rekel, čeprav mogoče z drugim poudarkom, ampak do istega pridemo.

\footnotetext{
9 http://centerslo.si/ 1o http://www.ung.si/sl/

11 http://admin.cambridge.org/nr/academic/subjects/languages-linguistics/grammar-andsyntax/series/cambridge-syntax-guides 12 Nizozemska znanstvena fundacija (NWO): https://www.nwo.nl/en

13 https://doi.org/10.1017/CBO9780511486227
} 
Kakšne so potrebe po slovničnih podatkih $v$ raziskovalni skupnosti in izobraževanju ter kaj bi trenutne težave najbolj rešilo? Spet pridemo do tega, da odvisno, koga vprašamo. Če vprašate mene, kakšen tip slovnice nam lahko pomaga z vidika ciljev teoretičnega jezikoslovja: ja, splošna opisna slovnica posameznega jezika, v tem primeru slovenščine - seveda nam lahko pomaga. Teoretično jezikoslovje jo bo jemalo za nabor podatkov, s katerimi odgovarja na teoretična vprašanja, in $\mathrm{v}$ istem smislu bo dobrodošel tudi projekt, ki bo proizvajal take podatke. Teoretično zasnovana razlagalna slovnica je absolutno lahko koristna mojemu tipu jezikoslovca, ker jo lahko uporabljam ne samo kot podatke, ampak že tudi za analizo. Še ena stvar, ki je vsekakor potreba v raziskovalni skupnosti, je vključevanje slovenskih podatkov v mednarodne baze slovničnih zgradb, kot je recimo World Atlas of Language Structures ${ }^{14}$ in podobne stvari. Terraling ${ }^{15}$ je še konkretno za skladnjo. In podobno.

Prva stvar (ki sem jo dal na konec) je: Kdo so deležniki, ki bi lahko projektne rezultate uporabljali? Če bojo korpusi nadgrajeni, bomo nove podatke seveda lahko uporabljali praktično vsi sinhroni jezikoslovci in uporabljala [jih] bo lahko širša javnost. Ena stvar, ki je omenjena v opisu projekta, je »na tem osnovana jezikovna analiza «; kar se tega tiče, pa vem premalo, da bi lahko sodil, kdo jo bo lahko uporabljal in ali jo bom jaz lahko uporabljal. To je to, kar imam povedati, hvala.

Špela Arhar Holdt: Jaz sem vas opazovala in sem hitro videla, da si zapisujete ob nastopih, tako da sem prepričana, da imate pripravljenih že kar nekaj replik. Bi pa vseeno rada najprej dala besedo Simonu kot vodji projekta in izpostavila dve stvari, ki se mi zdi, da sta se tukaj nakazovali, pa bi jih bilo mogoče dobro najprej razčistiti. Prva stvar je vprašanje celote proti parcialnosti in vprašanje, ki je po moje tukaj ležeče spodaj: ali lahko korpusni pristop, ali lahko empirija, kot si prej rekel, v resnici ponudi celovitost, ki jo lahko kdorkoli za kakršenkoli namen od slovničnega opisa pričakuje. Se ti zdi, da je to zdaj 
možno in na kakšen način je možno? Druga stvar je pa mogoče na ravni same priprave kakršnegakoli produkta, kjer smo ponovno govorili o celovitosti napram parcialnosti. Zdaj imamo dve izkušnji. Imamo enega zelo prominentnega slovničarja - mislim kot arhetip v našem prostoru - ki samodejno prevzame nalogo, ko se ta pojavi, in jo potem tudi nekako celovito reši; in na drugi strani izkušnjo, o kateri je prej govorila Amália ${ }^{16}$ in ki se je Oddelek za slovenistiko očitno ne lotuje - in je tudi jasno in razumljivo, zakaj ne: nabor jezikoslovcev, ki so specializirani za različna področja in potem skupaj menda sposobni kreirati celoto, če je to v resnici sploh mogoče. Se pravi, kakšna je rešitev v smislu ekipnega dela?

Simon Krek: Bom odgovoril tudi na to vprašanje. Najbrž je treba za začetek nekaj razumeti. Takoj, ko s podatki naredimo karkoli izven tega, da samo zapišemo, kaj je nekdo napisal ali rekel - dodamo neke meta[podatke] - takoj pademo v slovnični opis. Temu se enostavno ni mogoče izogniti. Treba je razumeti, da ko pademo $\mathrm{v}$ to past, se vsaj pri slovenščini znajdemo na natezalnici med dvema poloma. En [pol] je opis, ki je neprilagojen za to, da bi lahko naredil oziroma uporabil primerljive kategorije za drugi del te natezalnice, ki je mednarodni. Ko moraš svoje korpuse ali jezikovne oznake ali karkoli vključiti v mednarodni prostor, padeš v to, da te nekdo vpraša: »Imate samostalnik?« --»Okej, imamo.« -- »Imate tole?« -- »Ja, imamo.« -- »Kaj pa tole?« -- »Hm, mogoče imamo, mogoče pa nimamo, « in tako naprej. Ampak to $\mathrm{v}$ tem prostoru v bistvu ni dopuščeno. Lahko rečeš: »Tole bom uporabil na ta način, to bom uporabil na ta način. "Moram reči, da je mednarodni vidik na nek način olajšanje, ker izstopiš iz popolnoma enojezične situacije, kjer nad tabo visi veliki lik slovničarja in nikamor ne moreš. Če imaš na drugi strani prisilo, kjer nekdo reče: »Aha, frazni glagoli.« Frazni glagoli v angleščini, ne vem, kje. Mi rečemo: »Jah, nimamo fraznih glagolov, kaj hočemo.« Se pa začneš

\footnotetext{
${ }^{16}$ Vabljeno predavananje na projektnem dogodku: dr. Amália Mendes (Centro de Linguística da Universidade de Lisboa): Planning and Writing the Comprehensive Grammar of Portuguese.
} 
spraševati o vseh teh fenomenih in padeš $\mathrm{v}$ situacijo, kjer je mednarodna primerljivost oziroma uporabnost kategorij zapoved. Nujnost je. Ne samo ker imamo to radi, ampak ker je treba slovenščino procesirati na isti način kot vse ostale jezike. To je del, kjer se ni mogoče izogniti računalniški slovnici, ki ima pedigre $\mathrm{v}$ znanstveni slovnici - ki pa ni čisto isti, ampak je prej ovira kot ne.

Na drugi strani bom reagiral na ta, bom rekel, 'naj cveti sto cvetov' - imamo podatke, vsak vzame posamezni teoretski okvir in dela, kar hoče. Imamo lok med nujno mednarodno računalniško slovnico, ki je povezana (hkrati pa ne) z bivšo ali neobstoječo znanstveno slovnico, ki je po nujnosti povezana tudi s pedagoško slovnico; to je stvar, ki jo prostor sam zahteva, ker imamo šole, imamo učitelje slovenščine, nekaj morajo povedati o slovenščini. Se pravi, pedagoško slovnico rabimo. Po mojem ne bi bilo preveč pametno, da se to raztrešči. Ko računalnik procesira, je to čisto nekaj drugega. Osebku rečemo ena, dva, tri, štiri. ${ }^{17} \mathrm{~V}$ šoli se še vedno učijo o osebkih, ni pa čisto isto in nobeden točno ne ve, kaj je eno in kaj je drugo. Kar po mojem pomeni, da je potreben napor za to, da se situacijo razume in se vsaj v osnovi vzpostavi konsenz okrog osnovnih stvari. Potem lahko seveda gre vsak gojit svoje cvetove na svojo stran, ampak del, ki je trdno jedro 21. stoletja, dokler še imamo izobraževanje, je po mojem nujen. Toliko bi jaz imel o tem povedati, da ne bom preveč nakladal.

Špela Arhar Holdt: Ok, lahko, ja, kar.

Kozma Ahačič: Samo na eno stvar bi se odzval, čisto tako mimogrede. Jaz mislim, da so časi velikega slovničarstva že mimo. Vsaj v mlajši generaciji jih ni več čutiti. Mislim, da smo kljub vsemu vedno bolj v času, ko ljudje nimajo časa, da bi o jeziku ne vem kako razmišljali in zato želijo čim lažjo rešitev vprašanj. Ne gre pa več za to, da bi nekdo s pozicije moči, kot je bilo pred dvajsetimi, tridesetimi leti, karkoli skušal zapovedovati. Mislim, da se je tu ozračje bistveno sprostilo. Mogoče bi opozoril še na eno stvar, ki se mi zdi zelo pomembna, in je nanjo opozoril Marko, pa mimogrede tudi Irena. Slovnični opis v osnovni šoli

17 http://www.slovenscina.eu/tehnologije/razclenjevalnik 
(pa če se ga v osnovni šoli ne naučijo do konca, tudi v srednji šoli) dejansko nima primarne funkcije učenja slovenščine, ampak ima primarno funkcijo jezikovnega opisa na splošno. Glede na to, da govorimo slovensko, se ga pač aplicira na slovenščino. Kljub vsemu se mi zdi zelo pomembno, da ne pozabimo, da namen pouka slovenščine ne more biti samo to, da bomo bolj kompetentno uporabljali slovenščino, ampak tudi to, da se spoznamo z jezikoslovjem kot znanostjo, da dobimo nek osnovni uvod v jezikoslovje.

Špela Arhar Holdt: Lahko, razen, če bi ti na tole repliko?

Irena Krapš Vodopivec: Čisto kratka replika na to zadnje. Se strinjam, da opis jezika v šolah mora biti. Strinjam se z Markom, ki je rekel, da morajo biti stvari poimenovane, in mislim, da se ponovno vrača, da so tudi v osnovni šoli slovnični pojmi poimenovani. To je bila ena izmed stvari, ki jih jaz tudi ves čas poskušam in zagovarjam. Se pravi, osnoven slovnični opis, definirani slovnični pojmi, neko temeljno znanje, ki bi ga $\mathrm{v}$ osnovni šoli morali usvojiti in ga $\mathrm{v}$ gimnaziji in srednjih šolah mogoče malenkost nadgraditi, sicer pa utrjevati. Ampak moja misel je bila: iz rabe. Ne da bi popolnoma opustili slovnični opis, ampak da bi ob svojih izdelkih ta opis spoznavali. To je bila moja misel. Druga stvar pa je, da se na nek način strinjam, da mora biti opis jezika zaradi opisa samega, kot je rekel Kozma, vendar je temu namenjenega veliko, veliko preveč časa. In potem zmanjka za primarni cilj, ki ga vidim. Samo to, to sem mislila.

Špela Arhar Holdt: Ok, a lahko kar Roku?

Rok Žaucer: Več stvari, ampak vsako čisto na kratko. Pedagoška slovnica: ja, nikakor nisem rekel, da ne rabimo pedagoške slovnice. Hočem samo reči, da neka osnova itak obstaja. [Od nedavnega] obstajata tudi dve pedagoški slovnici, ampak obstajajo učbeniki, ki se uporabljajo, in ti operirajo ravno z osnovnimi stvarmi. Starejši mogoče malo bolj eksplicitno s 'pridevniki' in 'samostalniki', ki se jih pač ne bomo znebili in ni razloga, da se jih poskušamo znebiti. Nikakor ne bi hotel reči, da tega ne rabimo. To rabimo in to tudi obstaja. Potencialno se lahko reče: $\mathrm{v}$ taki meri, da je povezljivo s poučevanjem tujih jezikov, in imamo 
osnovo že fajn omejeno.

Kar se utilitarizma tiče, je vsekakor nekaj, kar mi gre na živce. [Da bi bil] pouk slovenščine namenjen samo učenju tega, da se boš naučil govoriti. Ideje (kar je Kozma omenil) sploh ni. Vsaj v osnovni šoli, pa tudi v srednji šoli ne. Če pomislite na biologijo: nobeden ne bo rekel, da ne rabimo biologije, ker še zmeraj ne tečemo hitreje ali kaj podobnega, čeprav nas učijo, kako deluje človeško telo. Tega ne razumem.

In še empiričnost. Malo se tudi pretirava s tem, da se delamo, kot da je zdaj vse novo in se dela empirično, včasih se pa ni. Toporišičeva slovnica je bila empirična in SSKJ je bil korpusno narejen. $\mathrm{V}$ drugih časih, na drugačen način - da ne eno ne drugo ne izhaja iz nobenih podatkov, pa ne moremo reči. Danes nam je pač omogočeno marsikaj drugega in lahko delamo na super boljše načine. Ampak delali so pa že Pleteršnik pa Tesnière s svojo dvojino. So pač nabirali podatke, delali so korpuse.

Špela Arhar Holdt: Ok, jaz bi Marku dala zdaj besedo.

Marko Stabej: Bom požrl besedo, da se ne bom oglasil. Je res, seveda niso delali čisto na pamet. Ampak delali so z gradivom, ki je bilo večinoma že obdelano. Dekontekstualizirano gradivo od marsikje. Pri Pleteršniku je znano, da pravzaprav na koncu niti ni vedel, od kod je marsikaj. Še posebej pa ne, iz katerih tekstov je. Ta dekontekstualizacija slovničnega opisa je še zdaj problem. Na nek način jo gledam pravzaprav pri Ahačičevih slovnicah. Seveda je dobro, da podobno kot pri biologiji izveš, kaj so kodoni in kaj so nevemkaj, tudi pri jezikoslovju izveš. Ampak če pogledamo objektivno: smeri v biologiji, ki bi o isti stvari trdile zelo diametralno nasprotne stvari, kolikor jaz vem, ni. V jeziku pa so in tudi v javnem življenju se zadnje čase kaže, kako je zelo hitro lahko podcenjevati - upravičeno podcenjevati - publiko in ji prodati marsikaj, kar bi ob poprejšnji kritičnosti zavrnila. Da rečem konkretno, če učencem rečeš: »Prilastkov odvisnik. Prilastkov odvisnik dobimo tako, da iz stavčnega člena tvorimo stavek.« Čemu služi tako védenje samo po sebi? Jaz nisem napisal 
slovnice in je tudi nikoli ne bom. Nisem zmožen tega, ker preveč kompliciram. Ampak [vsebina] v tem smislu: Kako lahko izrazimo čas v izjavljanju? Lahko tako, da imamo neke specializirane izraze, včasih pa uporabimo v stavku in temu rečemo odvisniki.

To je zdaj parcialno - vprašanje metode, vprašanje tradicije in tako naprej. Ampak se mi zdi, da če je bil od leta '98 naprej pouk slovenščine nominalno funkcionalističen ( $v$ resnici je bil afunkcionalističen, ampak to je stvar didaktike in ocene), zdaj ni čas, da gremo nazaj v formalizacijo in rečemo: »Aha, to je seznanjenje, vstop v jezikoslovno znanost. « Jaz tega ne vidim kot v vstop v jezikoslovno znanost. Niti slučajno ne. Vstop v vsako znanost je pač čudenje, ne pa ponujanje vzorcev, da si pravzaprav omejiš svojo radovednost na način, da drugače niti ne znaš gledati. In to je korpusno jezikoslovje definitivno veliko bolj približalo: da vidiš, ne kako je že nekdo opisal. [Ker da je] Toporišič na gradivu nastal - Rok, večina je prepisana iz gradiv prejšnjih slovnic in to vsi vemo. On je sicer govoril, da je normiral ta jezik na podlagi izobraženca iz središča, srednjih let, nek demografski [kriterij], ampak ni bilo jasno, kje se to vidi. Nikjer ni niti serije izjav. Ni izmišljeno, ampak ni pa to tip podatkov, kot ga ponuja korpusno jezikoslovje.

Ki je pa grozno, saj se dejansko ne moreš znajti, to je pa res. Brez vmesnikov je večina nas, ki smo simpatizerji tega jezikoslovja, bosih. Če ne najdeš vodnika po peklu podatkov. To je res in mislim, da je tudi tukaj treba konvergenco graditi bolj, čeprav si Društvo za jezikovne tehnologije ${ }^{18}$ od leta '98 (ali še prej) prizadeva za to konvergenco. Živimo v svetu, ko smo na Oddelku za slovenistiko opazili, da če hočemo literati in jezikoslovci prijaviti skupen projekt, moramo prijaviti interdisciplinarni projekt. Ja, ker literarna veda in jezikoslovje nista ista veda. Pa tako naprej. Skratka, zdi se mi, da je en vidik slovničarstva tudi to, da dva svetova prideta skupaj na operativen način.

Špela Arhar Holdt: Jaz imam [ta svoj mikrofon], hvala. Prej ko si govoril, si

$18 \mathrm{http} / / /$ www.sdjt.si/wp/ 
omenil, da podatkov ni nikoli premalo. Si zdaj hotel povedati, da je podatkov lahko preveč? Je to tvoje mnenje?

Marko Stabej: Občan Marko Stabej, ki zjutraj gleda v računalnik, [meni, da] je podatkov preveč. Ker če mora čez dve uri govoriti, kaj je tako in se zdi na korpusnih podatkih, pa podatki podrejo vse hipoteze, ki jih imaš za neko stvar - jih je preveč. Na načelni ravni jih pa ne more biti preveč. Če lahko iz svoje pedagoške izkušnje, ki je glede uporabe korpusa razmeroma šibka, ampak: študentje začnejo uživati, če lahko [brskajo] po sinhronem korpusu Gigafida19, hitro grejo tudi v IMP ${ }^{20}$ pogledat, kako je bilo včasih. Zdaj se že pritožujejo, da od leta ' 18 do leta 1990 ni nobenega korpusnega podatka, kje pa naj tam dobimo podatke. Ja, ne vem, kaj, zgradite jih. Nastane potreba, da ne govoriš na pamet in da ne govoriš: »To je že v Pleteršniku in vemo, da je bilo prej že v Pohlinu, pa Pohlin je prepisal iz Belostenca, « pa to, ono, tretje. To je bila včasih nit podatkov, zdaj pa je podatkov o marsičem premalo in ostanem pri tem, da jih je zmeraj premalo.

Špela Arhar Holdt: Okej. Ja, kar.

Irena Krapš Vodopivec: Lahko še jaz repliciram, saj bom na kratko. Zdi se mi, da je pomembno, da se vprašamo, kaj bi radi, glede na vse, kar je bilo do zdaj povedano. Kaj bi radi v šoli oziroma pri pouku slovenščine dosegli? Prej je bilo rečeno, da potrebujemo tudi opis zaradi opisa samega. Spet bom čisto konkretna: eno generacijo sem analizirala oziroma statistično preverila, koliko so uspešni na posameznih področjih. Če gledamo samo sposobnost reprodukcije opisa jezika, so uspešni blizu prav dobre ocene, če govorim o ocenah. Takoj ko gremo k nalogam višje taksonomske stopnje, kakršne so na maturi, smo za celo oceno ali še več nižje. Govorim o povprečni oceni ene generacije skozi vsa štiri leta, [to] je nek vzorec. Ko gremo k eseju, še k nadgradnji vsega skupaj, smo nekje na dobri oceni. To je generacija na naši

19 http://www.gigafida.net/

20 http://nl.ijs.si/imp/ 
srednji šoli oziroma gimnaziji. Podatki na slovenski ravni, sem pa že rekla: lansko leto so bili rezultati porazni. Če gledamo primerjalno s tujimi jeziki, za eno oceno nižje. S tem da moramo upoštevati, da govorim o tujih jezikih na višji ravni, ker je tudi slovenščina na višji ravni. In ob védenju, da je bilo za pozitivno pri slovenščini potrebno doseči $47, \mathrm{v}$ določenih primerih celo samo 38 točk od 100 (se pravi, v procentih). Pri tujih jezikih pa 50 \%. Vprašati se moramo, kaj pravzaprav želimo v tistih parih urah, ki jih profesorji oziroma učitelji slovenščine pač imamo.

Samo še eno stvar, npr. konkretno v oblikoslovju. V drugem letniku gremo ponovno skozi celo oblikoslovje. (Imam tudi sina v osnovni šoli in poznam potek osnovnošolskega šolanja, ker sem tam učila. Tudi tam spoznajo praktično vse temeljne pojme oblikoslovja.) Ker vodim mape svojih dijakov, lahko rečem, da vem, katere napake skozi štiri leta delajo. Recimo: ki, kateri. Dijak ve, kdaj se uporablja ta zaimek, kdaj enega, kdaj drugega. V esejih pa seveda to dosledno uporablja narobe. Ko sem jih vprašala (spet je v ozadju anketa - anketirala sem 150 dijakov), ali razmišljate o tem, katero pravilo uporabljate, ko tvorite besedilo, je bil odgovor skoraj 100 \% negativen. Ja, absolutno slovnični opis, ampak jaz pravim: iz lastne rabe oziroma iz lastnega tvorjenja in res temeljni slovnični pojmi. Hvala lepa.

Špela Arhar Holdt: Se opravičujem, ampak imam še eno podvprašanje, ker si odprla točno to, kar sem hotela poizvesti, in sicer: se ti zdi, da smo kot raziskovalci, kot akademiki, ki v resnici nimamo dostopa do šolskega sveta, nimamo dostopa do tvojih izkušenj, sposobni pripraviti pedagoško slovnico, ki bo odgovarjala na te potrebe? Ali je to nekaj, kar bi morali v bistvu učitelji sami pripravljati - če gre za vprašanje uporabnika, se pravi nekaj, kar mora izhajati od uporabnika, ki ga mi ne poznamo. Kaj je po tvojem mnenju rešitev?

Irena Krapš Vodopivec: Ja, absolutno povezava s praktiki. Vedno povezava s praktiki. Tudi pri maturi, ki se jo oblikuje, bi morala biti povezava s praktiki. Raziskovalci in učitelji praktiki, to bi moralo biti razmerje 50:50. To je to. Še to 
bi rekla, ko govoriva o tem, kdo bi moral. Vprašati se moramo o našem šolskem sistemu: ni morda vendarle treba premisliti o načinu, kako preverjamo znanje? To mene ves čas muči. Kako preverjamo znanje slovenščine znotraj šolskega sistema in seveda na tej grozni končni postaji mature. Slovenist bi moral razčlembo neumetnostnega besedila, se pravi celotni slovnični, pravopisni in pravorečni opis, rešiti v tridesetih minutah. To je ekvivalentno devetdesetim minutam, ki jih ima na voljo dijak. Nimam sicer reprezentativnega vzorca, imam pa nekaj profesorjev slovenščine, ki so to rešili. Redkokateri 100 \%, ker zmanjka časa tudi profesorju slovenščine. Dala sem pa [v reševanje] določenemu številu drugih profesorjev (spet ni reprezentativen vzorec, delam na tem), se pravi strokovnjakom drugih področjih, in to univerzitetno izobraženih strokovnjakov. Verjemite, da smo blizu med 20 in 30 \% rešenega testa. Moramo se torej vprašati, kaj je sploh namen takega preverjanja in šele posledično, kako spet spremeniti - če že - karkoli v šolskem sistemu pri podaji. Hvala lepa.

Špela Arhar Holdt: Zastavim vprašanja, ali je kakšna replika? V zvezi s temo, o kateri sta prej govorila Marko in Irena, se mi zdi, da imaš ti največ izkušenj s pripravo slovnic, ki že živijo v razredih. Tukaj je bil narejen korak, ki je na nek način mogoče neintuitiven, zanima me tvoje mnenje. V odsotnosti - če se strinjava - sodobne znanstvene slovnice je bila pripravljena pedagoška slovnica in ta pedagoška slovnica je morala na nek način nagovoriti tudi neke vrzeli. Ti si recimo uporabljal tudi korpusno gradivo iz korpusa Šolar, kar je korak proti uporabnikom. In zdaj me zanima, če gre za spremembo koncepta, ki je vseeno nadgradnja? Kaj se zgodi, če tvoj koncept preslikamo nazaj na znanstvena izhodišča? Kaj se ti izkaže, kakšna je po tvojem mnenju logična nadaljnja [slovnična] pot?

Kozma Ahačič: Jaz bi tudi še enkrat poudaril ločevanje med podatki (da ne bom vznemirjal) in teoretičnim opisom. Bistvo vsake slovnice je namreč interpretacija podatkov in potem abstraktizacija te interpretacije, zato da podatke lažje razumemo. Če pogledamo v zgodovino in če se ozremo v svet, je 
praviloma razlika med šolskimi in znanstvenimi slovnicami velika. Ni nujno, da je to neposredno povezano, se pa strinjam, da je uporabno, če govorijo šolske in znanstvene slovnice vsaj v osnovnih pojmovnih konceptih isti jezik. Slovnica je namreč tudi osnova za izdelavo vseh ostalih priročnikov, zato ker z nekim kvalifikatorjem lahko povemo tudi v slovarju več, kot če bi to morali razlagati na dolgo. Skratka, da bi imela šolska slovnica vpliv na znanstveno slovnico, bi bilo neumno. Dejstvo pa je, da če bo nastala znanstvena slovnica, bodo vse šolske slovnice zajemale iz gradiva, iz podatkov, ki jih bo znanstvena slovnica zbrala, in seveda tudi iz vseh ostalih dostopnih podatkov. Hkrati bi opozoril še na potrebo po neki srednji poti. To je slovnica, ki ob samem opisu opisuje podatke še z vidka norme. To se mi zdi potrebno zaradi tistih uporabnikov, ki normativne podatke pričakujejo in ki nimajo dovolj znanja, da bi se čutili sami sposobni presoje ali pa presoje niti ne želijo. Skratka, splošna slovnica za vsakogar (ne le za mlade, za učenje) bi bila zagotovo tudi zelo dobrodošlo dopolnilo širše zasnovane znanstvene slovnice, za katero je pa nemogoče, da jo napiše en sam - v današnjem času in $\mathrm{z}$ današnjimi podatki.

Špela Arhar Holdt: Samo to bi še rada vprašala, ker zdaj gremo počasi, da imajo ljudje malo več časa za debato. Rekli smo, da je ena stvar, o kateri bi se danes res radi pogovarjali, kdo so deležniki, kdo bo uporabljal te podatke. Če ta projekt pripravi podatke, te vprašam kot vodjo programske skupine: ${ }^{21}$ se ti zdi to nekaj, kar bi na inštitutu lahko uporabljali za pripravo nove slovnice? Ali se ti zdi, da je vseeno?

Kozma Ahačič: Verjetno ne samo za pripravo nove slovnice. Tudi pri vseh ostalih raziskavah, pri vseh ostalih aktivnostih. Vsaki novi interpretirani podatki so v slovenskem prostoru, kjer tega res ni veliko, velik plus. Še toliko večji, ker je tega dejansko premalo.

Špela Arhar Holdt: Simon, imaš repliko?

21 https://isjfr.zrc-sazu.si/sl/programi-in-projekti/slovenski-jezilk-v-sinhronem-indiahronem-razvoju-1\#v 
Simon Krek: Ja, imam par stvari za povedati. Začel bom pa od zadnjega konca. Do zdaj v resnici nisem slišal, da bi kdorkoli v tem raziskovalnem prostoru deklariral, da bo naredil novo slovnico. Tako da prvič slišim, da bo ta raziskovalni program dejansko naredil slovnico. Mislim, to me veseli.

Špela Arhar Holdt: Če je bilo to rečeno, ja.

Simon Krek: Ne samo, a ne.

Kozma Ahačič: Ni bilo rečeno.

Simon Krek: Aha, ni bilo rečeno. Ker je bilo rečeno: "Ne samo za slovnico, ampak tudi za druge stvari.« Jaz sem nekako razumel, da je to potem prva stvar ob vseh ostalih zadevah. Okej, potem to ne drži. Se pravi, se nihče v resnici še ni javil, da bi naredil slovnico.

Druga stvar je ta. Meni se zdi, da govorimo malo mitološko, v smislu: »Imamo šolsko slovnico, potem je znanstvena slovnica, ki je čisto nekaj drugega in zapletena in grozno, in delaš jo trideset let in tako naprej«. Treba se je vprašati, kaj naj bi ločilo šolsko in znanstveno slovnico. Po mojem mnenju enostavno to, kar znanost je - da je osnovana na empiriji in na tem, da so ponovljivi preizkusi, podatki in tako naprej. Se pravi, da lahko z gotovostjo rečeš, da če bo kdo ponovil tvoj poizkus, recimo da bo rekel: »Zdaj bom pa tam našel ta in ta slovnični pojav, « ga bo v podatkih verjetno našel. Če ne, je tisti znanstvenik lagal. To je znanstvena slovnica, vsaj po mojem mnenju naj bi bila. Od pedagoške pa jo loči to, da se v šolskem prostoru ni treba ukvarjati s preverjanji preizkusov. In v resnici morajo vse šolske slovnice lagati, zato ker idealizirajo neko situacijo in vse robne pojave zanemarjajo, da bi podali osnovno informacijo o vseh jezikovnih pojavih. To je na nek način pozitivno laganje z dobrim namenom, zato da sporočaš in v edukacijskem sistemu pokriješ neko področje. Tako jaz razumem to razliko.

In zdaj smo dobili še eno slovnico, ki se ji reče 'normativna slovnica'. Na kar bi reagiral: to zame absolutno ni srednja pot, ampak je ekstremna pot. Ker je (vsaj 
v našem prostoru) bilo vprašanje, kje se pravzaprav norma dogaja. Do zdaj smo bili prepričani, da se dogaja znotraj pravopisa, pa znotraj pravil, ki pokrivajo še malo slovnice, potem se malo dogaja po slovarjih. Že SSKJ je bil deklariran kot informativno-normativni slovar, zdaj pa je novi SSKJ sploh deklariran na ta način. Kar pomeni, da bomo imeli vse troje: normativno slovnico, informativno-normativni slovar in še pravopis kot ultimativna norma. S tem po mojem začnemo na hujši način ločevati jezikovno realnost in to, kar je predpisano.

Kozma Ahačič: Jaz mislim, da ta pogled izhaja iz časov, ko je bila norma nekaj, kar je oteževalo življenje. Mislim, da so ti časi mimo. Nihče več, razen nekaj zapoznelih jezikoslovcev, ne bo več nikogar javno napadal, če bo normo zavestno kršil. Namen norme v sodobnem času je samo - ne normirati, ampak povedati, kakšna raba se zdi ob izbiri različnih možnosti najmanj zaznamovana, najbolj primerna za splošnega uporabnika jezika. Nikakor pa ni mišljena norma kot nek zakon, že dolgo. Saj imamo tu tudi nekaj pravopiscev, ki to že več let razlagajo in se je že zelo prijelo. Obsedenost z jezikoslovcem, ki rohni, ni več sodobno stanje.

Simon Krek: Samo eno vprašanje. Če imamo institucijo, ki dobi za svoje delovanje približno milijon evrov na leto in vodja te inštitucije razlaga o brezvestnih uporabnikih slovenščine, [tega] ne morem videti drugače kot ločevanje zrnja od plev - šestih uporabnikov jezika, ki ga znajo uporabljati, in vseh ostalih, ki po njem tacajo na vse mogoče načine. To ni pozicija, ki bi bila karkoli, ampak je pozicija znotraj določene družbe $\mathrm{v}$ določenem prostoru $\mathrm{v}$ določenem času.

Špela Arhar Holdt: Če je replika, bi z veseljem. Ni? Rok, tebe sem tudi videla nekaj odkimavati. Splošno odkimavanje [smeh].

Rok Žaucer: Kar se tiče norme, mislim, da je mogoče pogled, ki ga je Kozma zagovarjal, v jezikoslovju. $\mathrm{V}$ družbi na splošno nikakor ne in žal tudi nikoli ne bo. Tudi v jezikovno bolj liberalnih deželah obstaja norma kot nekaj, kar je pri 
delu govorcev nekaj, na podlagi česar se druge blati. To je obstajalo in bo zmeraj obstajalo - pri jeziku, pri oblačenju in pri vseh drugih stvareh.

Pri idealizaciji in laganju mi je prišlo na misel: pedagoška slovnica je v nekem smislu poenostavljanje in v tem smislu laganje. Ampak veliko stvari je v nekem smislu laganje in v nekem smislu idealizacija. Čomskijanstvo je nekaj, čemur se je zelo očitala idealizacija - da jemlje govorca in ne upošteva njegove real-time jezikovne produkcije in to je bil velik problem. Korpusi delajo veliko idealizacijo. Če delamo slovnico na podlagi korpusa, bomo izpovprečili in dobimo nekaj, za kar lahko rečemo: »To je standard, zato ker je povprečje«. Ampak idealizacija je v tem smislu, da če bomo vprašali posameznega govorca: »Ali sprejmeš to kot nekaj, kar je v slovenščini okej?« bomo dobili stvari, kjer bodo rojeni govorci slovenščine rekli: »Ne«. Povsod pač pridemo do zadržkov. Ne pravim in nikakor ne mislim, da je zato treba korpuse vreči skozi okno. Niti pod razno, korpusi so zelo uporabni. In korpusnih podatkov je premalo; tudi v obstoječih slovenskih korpusih sem iskal stvari, ki jih nisem našel, pa sem jih brez težav našel z Googlom. Zdaj je milijonkrat oziroma neskončno bolje, kot je bilo v časih Pleteršnika, kot je bilo rečeno. Kar pa ne pomeni, da Pleteršnik ni tudi delal empirično.

Špela Arhar Holdt: To se mi zdi super, zdaj moram preveriti pri publiki malo smo čez, ampak če ful uživate, mogoče gremo lahko še eno rundo replik. Uživanje lahko nakažete z razbrzdanim ploskanjem. [smeh] Vseeno moram še vprašati, ker absolutno nismo odgovorili, kam gremo, sploh ne. Povedali smo malo o tem, kje smo, malo o tem, kam bi bilo dobro zaviti. Zdaj bom vsakega posebej izzvala $\mathrm{z}$ istim vprašanjem: kdo bi po vašem mnenju moral uporabiti podatke, ki jih bomo naredili, zato da pripravi konkreten slovnični opis? Kakšna bi morala zgledati ekipa in kako bi moralo to potekati? Ampak na hitro. Zanima me. Simon, lahko ti začneš, ni problem.

Simon Krek: Kar mi izgleda zdaj po tej debati (eno uro pa petnajst minut) če zelo na kratko povzamem: pedagoški del lahko pustimo komercializmu in 
voluntarizmu, ker bodo wikiji nastajali, založbe bo pedagoški del zanimal, ker lahko dobijo povrnjene stroške za pedagoške slovnice. Računalniški del se bo zgodil po nujnosti sam po sebi, v resnici. Za znanstveni del pa se nobeden ne javlja in nikogar ta hip ne briga. To bi bil moj povzetek.

Špela Arhar Holdt: Okej, Rok?

Rok Žaucer: Kdo bi to moral uporabiti?

Špela Arhar Holdt: Ja, koga bi ti, recimo, videl v tem prostoru? Kdo bi bil, kaj bi bilo optimalno, kaj se ti zdi?

Rok Žaucer: Prva stvar je spet vprašanje, kakšno slovnico. Če se to uporablja za izdelavo nove slovnice, o kakšni slovnici govorimo. Če rečemo, da je zadnja v slovenščini napisana slovnica, ki se jo tipično označuje za znanstveno slovnico (pa nočem reči, da ni, ampak ni mi čisto jasno, kaj koncept znanstvene slovnice je), stara že skoraj petdeset let, potem je mogoče čas, da se naredi nekaj novega. Kdo bi to lahko naredil? Če drug ne bo, bi se po neki službeni dolžnosti, kar se mene tiče, moral tega lotiti ZRC. Službeni dolžnosti v smislu, [da ima] v družbi pač tako pozicijo, da bi to bilo prav. S tem, ko sem jim to naložil, nočem reči: »Saj imate finance, nimate financ. «V to se ne vtikam. Čisto možno, da bi za to rabili druge finance, ampak če kdo to je - to je tam.

Špela Arhar Holdt: V eni sekundi sem bila prepričana, da se boste javili generativa [smeh]. Okej, Kozma.

Kozma Ahačič: Zanimivo je, da se niti ruska korpusna slovnica ne dela z namenskimi financami in mislim, da bo tudi odločitev za slovensko znanstveno slovnico verjetno v večji meri sad odločitve neke skupine ljudi, da gre v to na prostovoljni bazi, kot pa sad nekega projekta; ker spraviti slovnico v projektni razpis, tudi če se ga razvleče na pet let, je operativno nemogoče. Sploh, če bi pri njej sodelovalo več ljudi. Jaz ne bom rekel, naj naredijo drugi. Rekel bom: če bi imel čas, ko bom imel čas, bi se tega z veseljem lotil. Ampak zaenkrat, v naslednjih letih, ne vidim te možnosti. Bi pa rekel še to. Zdi se mi zelo prav za 
naš prostor, da skušamo vstopati vanj z rezultati, ne s sanjanjem, kaj bi bilo dobro, sicer mine deset, dvajset, trideset let in se dejansko nič ne premakne. S tega vidika mislim, da bo ta projekt v vsakem primeru plus.

Irena Krapš Vodopivec: Kakšno slovnico naj bi rabili? Sem prav razumela? Špela Arhar Holdt: Ne, kdo jo bo naredil.

Irena Krapš Vodopivec: Bom šla s tega, kakšno. Mislim, da rabimo eno slovnico, ki naj bi nastala na podlagi korpusnih podatkov. Tukaj bi se po moji presoji združili vsi, tudi če so bili različnih mnenj, zato ker je v resnici idealizacija (kot je rekel Rok) manjša, če izhajamo iz ene ogromne baze podatkov, kot če izhajamo iz petih jezikoslovcev, ki se odločajo za najbolj optimalen opis. Se pravi: eno slovnico in potem pustiti ... Profesor slovenščine naj bi bil po končani fakulteti dovolj izobražen, da bi bil sposoben interpretirati to slovnico in tudi naučiti dijake jo v pravi meri uporabljati. Če bi bilo po moje, ne bi preveč ločevala na znanstveno in pedagoško in tako naprej slovnico.

Špela Arhar Holdt: Hvala, še Marko.

Marko Stabej: A sprašuješ o standardni ali kakšni?

Špela Arhar Holdt: O naslednji. Sprašujem o prioriteti in o tem, kdo.

Marko Stabej: Jaz bi tako rekel. Seveda se prepoznam v tem mečkaštvu, deset let razmišljaš, pa nič ne narediš. Ampak [vprašljiv] je tudi statement, da nekaj narediš, potem pa pogledaš: „Kaj sem pa pravzaprav naredil? « Tako se marsikaj naredi, ampak je vprašanje, kaj se s tem stori. Meni se zdi (razbralo se je, da ni samo moje mnenje tako): ideja o znanstveni slovnici z velikim $\mathrm{Z}$ trenutno ne more biti drugega kot neplemenita laž, če že lahko rečemo, da je pedagoška slovnica plemenita laž. Kar kaže vtis, da jezikoslovci ne znamo narediti znanstvene slovnice brez povezovanja $\mathrm{z}$ drugimi strokami, če to hočemo. Zato [sprašujem], kakšno. Standardnega jezika mogoče še in bi se strinjal z Ireno, da jo lahko vidiš kot kontinuum. Da pa pojasni jezikovno dejavnost v raznolikosti, ko enkrat imaš razgled nad to raznolikostjo ... Ne vem, 
zdaj imamo tudi spontani govor, [za tem] ko je jezikoslovje dolgo časa z gnusom zavračalo kakršenkoli podatek in poskrbelo, da ga ja ne bi bilo, da ne bi mi [raziskovali] jezika ulice in tako naprej. Če rečeš: »Nekaj bom predstavil kot znanstveno slovnico «, padeš v naslednjo jezikovnonačrtovalno past. Staro past SSKJ-ja, da nekaj mora imeti vsaka slovenska družina, ampak nikoli nihče razen jezikoslovcev, lektorjev pa mogoče še koga notri ne pogleda. Imeti znanstveno slovnico, ki bo znanstvena slovnica z zelo velikim $\mathrm{Z}$, pa ne bo pravzaprav ničesar znanstveno pojasnila in ne bo naredila ničesar dobrega za uporabni namen, ker tega ne more, kot je rekel Rok ... So zelo različne potrebe različnih publik, zato se mi zdi, da se nima smisla delati, da to bo.

Špela Arhar Holdt: Okej, hvala, zdaj pa publika, prepričana sem, da je ogromno vprašanj ... Vem, da ste utrujeni, izgledate ful utrujeni ... Jaz sem kar uživala, moram priznati; ni bilo tako zelo grozno. Ampak zdaj je priložnost, da pač poveste oziroma vprašate, komentirate ... Ja, Vojko.

Vojko Gorjanc: Jaz bom pravzaprav povedal svoje mnenje in se ne bom strinjal s kolegico Ireno Krapš Vodopivec, da rabimo eno slovnico. Meni se zdi, da (kar je kolega Žaucer omenil na začetku), rabimo veliko različnih. Predvsem slovenski prostor rabi veliko različnih, zato ker je navajen na en opis, ki v trenutku deluje avtoritativno - in se ga kot avtoritativnega tudi zlorablja. Zato se mi zdi, da je prvi korak k različnosti in šele potem k neki skupnosti. Zdi se mi, da je to boljši princip, kot pa načrtovanje nekega velikega projekta - ki bi si ga pravzaprav želel, ampak se mi zdi, da bi bilo tako za vse nas bolje, oddahnili bi si od tega vsemogočnega, absolutnega.

In drugo, mogoče samo na kratko o vprašanju slovnice, jezikovne kompetence, šole, spoznavanja jezikoslovja. To res lahko gre z roko v roki, samo če se pametno tega lotimo. Izgradnja jezikovne kompetence nikoli ne izključuje jezikoslovja, je pa vprašanje točno to, kot je rekel kolega Stabej: katerega in kakšnega jezikoslovja. Kar je kot jezikoslovje trenutno razumljeno v slovenskem prostoru (tudi v slovenskem šolskem prostoru), je nekaj, kar je veliko bolj 
konzervativno, kot je bilo $\mathrm{v}$ času usmerjenega izobraževanja. V času usmerjenega izobraževanja je bil šolski prostor v resnici veliko bolj odprt za poststrukturalne kritične pristope in nas je naučil tudi kritičnega mišljenja. Kakršnegakoli že takrat, vendarle kritičnega mišljenja. In če si kaj želim o jezikoslovju, je ravno kritično mišljenje in kritični pristop - zato, da opremimo dijake in kasneje študente z jezikoslovnimi znanji, da bodo k vsemu v svetu znali humanistično pristopati, kritično. Zato me veseli izhodišče današnjega celotnega dogodka, to je predstavitev portugalske slovnice, kjer je kolegica Amália Mendes čisto na začetku pokazala strukturo slovnice in obsežno poglavje, ki je sociolingvistično. Ki je zelo kvaliteten, kritičen sociolingvistični opis stanja portugalščin, in je del slovnice. Kar pomeni, da ko govorimo o slovnici, pravzaprav lahko govorimo o marsičem; in hkrati, ko govorimo o jezikoslovju, se moramo zavedati, o čem vse govorimo. Premalokrat govorimo o vsem mogočem. Govorimo o samo enem tipu jezikoslovja in samo to imamo v glavi, ko govorimo, da bomo naučili dijake tudi nekaj jezikoslovja. Jaz si takega jezikoslovja, tudi potem, ko pridejo na študij, pravzaprav niti ne želim. Veliko raje bi jih imel opremljene s popolnoma drugimi znanji in védenji.

Špela Arhar Holdt: Hvala. Če ima kdo od panelistov slučajno repliko ali kakšen dodaten komentar na to izjavo ... [prekinitev $v$ posnetku]

Helena Dobrovoljc: [prekinitev $v$ posnetku, zapis po spominu govorke] Mogoče je moja replika manjša zastranitev od sodobnih načrtov, a se mi zdi pomembna. Ko smo ob 9o-letnici rojstva Jožeta Toporišiča pripravljali razstavo o njegovem delu, smo predstavili tudi korespondenco, ki do sedaj še ni bila objavljena. Med pismi najdemo tudi prošnjo Antona Bajca, akademijskega slovničarja in kasneje enega vodilnih slovaropiscev pri SSKJ, z vabilom, da bi se Toporišič [nadaljevanje zapisa po posnetku] vendarle pridružil ekipi na SAZU, ki bi morala pripraviti novo slovnico, saj je njihova ${ }^{22}$ zastarela in ob vsej leksikalni ekspanziji, ki jih je z medijsko revolucijo dosegla, enostavno niso bili 
več sposobni v modelu predvojne breznikovske slovnice opisati novega sistema. Toporišič je to, kot veste, zavrnil, tudi zato, ker se je bal, kako bo lahko v okviru kolektivnega dela na SAZU s svojimi idejami tako prodrl kot individualist lahko na Filozofski fakulteti. Bil je sam avtor in ne del kolektiva. Je pa zanimivo, da na SAZU-ju potem te želje niso uresničili mimo Toporišiča in da se je celotna strokovna javnost zadovoljila z individualno slovnico, ki pač skozi prizmo enega človeka kaže na jezikovni sistem. Vendar je kljub drugačnim mnenjem, ki prevladujejo, Toporišičeva slovnica izredno šibko normativna, kar se izrecnih prepovedi tiče. On na primer pravi: »Slovničarji že dolgo prepovedujejo [ta pojav].« Ne napiše: »Jaz tudi prepovedujem, « ampak opisuje prevladujoče. Vsi vemo, da so bile veliko bolj izrecno normativne vse nadaljnje aplikacije te slovnice. V veliki želji po - kako bi se reklo - kodifikacijski vnemi, je to potem šlo in v slovarje in v pravopise in tudi v različne lektorske priročnike in še dlje in še dlje. Meni se zdi razmejitev med opisnim in normativnim danes drugotna in to odsevajo tudi novi koncepti, ki smo jih pravopisci že predstavili. [Ne gre] delati »znanosti« iz tega, da imamo nekje dvojnico npr. Zidanega Mostu ali Zidanega Mosta, temveč ločiti med slovničnimi dejstvi in stilističnimi skladenjskimi napotki.

Moje osebno stališče je, da je problem poststrukturalne slovnice vse bolj problem [opisa] nenadzorovane rabe jezika, torej usklajevanje pisnega jezika $\mathrm{z}$ govorjenim. To nam očitno povzroča težave, in še dobro je, da je tako. Potrebujemo pa slovnico, ki bo ob verodostojnih podatkih ponudila utrditev slovničnih konceptov, ne pa slovnične terminologije. In tukaj se mi zdi, da velja: kolikor jezikoslovcev, toliko različnih definicij. [Polstavčni prilastek, polstavek in npr. povedkovnik ...] Kdo od jezikoslovcev danes to [heterogenost] obvladuje? Se pa vendarle nenehno ponavlja, utrjuje. Vprašanje slovničnega koncepta, mislim, je temeljno vprašanje tudi za pedagoško slovnico. In različne slovnice, ki služijo različnim namenom. Tukaj se strinjam z Vojkom. Hvala.

Špela Arhar Holdt: Hvala za mnenje in mogoče tudi implicitno vprašanje, če se je kdo pripravljen odzvati. Ne? Ekipa je utrujena, vsi želijo domov ... Če ima 
še kdo kakšno vprašanje, z veseljem, bom kar vztrajala. Edina možnost je pobeg [smeh]. Ja, Polona.

Polona Gantar: Jaz bi imela dva komentarja na izjavi. Prva je bila mogoče (vsaj jaz sem jo tako razumela) izražena kot bojazen, da govorimo o slovnici, ki je stranski produkt jezikovnotehnoloških potreb. Meni se zdi, da je to zelo preprosto dojemanje te smeri. Izkušnje, kar jih imam, odkar delam s korpusi, pa tudi zdaj pri pripravi podatkov znotraj tega projekta, so ravno obratne. Takrat, ko je jezikoslovec zadovoljen s formaliziranim opisom, ki ga ponudi računalničarju, takrat je ta opis dober. Torej je smer ravno obratna. Drugi komentar, ki je s tem na nek način povezan, je to, kar že tudi srečujem v tem prostoru: konsenz, da je korpusni pristop pravzaprav samo metodologija, ne pa teorija. No, jaz se s tem ne strinjam. Zlasti na področju pomenskih raziskav je ravno korpusni pristop ponudil nove teoretične rešitve. Postavljanje leksikalne gramatičnosti v prvi plan je prav gotovo tak teoretični pristop. Samo toliko.

[zaključek posnetka]

\section{ZAHVALA}

Izvedba panela in njegov zapis sta nastala v okviru projekta ARRS J6-8256 Nova slounica sodobne standardne slovenščine: viri in metode. Projekt sofinancira Javna agencija za raziskovalno dejavnost Republike Slovenije iz državnega proračuna. 
To delo je ponujeno pod licenco Creative Commons: Priznanje avtorstvaDeljenje pod enakimi pogoji 4.o Mednarodna.

This work is licensed under the Creative Commons Attribution-ShareAlike 4.0 International.

https://creativecommons.org/licenses/by-sa/4.o/

(C) (1) () 